\title{
Evangelism in the Era of New Media
}

\author{
Barigbon Gbara Nsereka ${ }^{1}$, Ph.D, \& Tessy Nwanze ${ }^{2}$ \\ ${ }^{I}$ Department of Mass Communication, Rivers State University, Port Harcourt, Nigeria \\ ${ }^{2}$ Postgraduate Student, Department of English and Communication Art, Ignatius Ajuru University of Education, Port Harcourt,
} Nigeria

\begin{abstract}
Considering that a great many new media users can be gratified by contents other than religious messages on the Internet, one wonders how evangelism will fare in this era of the new media. Besides evangelism, the new media are used for education, information, socialization and entertainment. However, churches which are ignorant of the potency of online evangelism are believed to be missing out on what is supposed to help them broaden the frontiers of fulfilling The Great Commission. This position paper which is an offshoot of a rigorous empirical study is, therefore, done to examine the practice of online evangelism by evangelical churches in Port Harcourt. Investigation shows, among other things, that the social media are veritable instruments in sustaining old members and wooing new ones. The study concluded that the churches that use the social media platforms are up-to-date; the social media used in evangelism are perceived as attractive and satisfactory; but that the cost of maintaining the new media workability is prohibitive. It was then recommended that despite the unethical and immoral posts that can be found online, the new media should not be avoided because of its potency in fostering bonds among old church members and evangelizing prospective ones.
\end{abstract}

Key Words: Televangelism, Evangelical churches, New media, Social media, Port Harcourt

\section{INTRODUCTION}

$\mathrm{B}$ eyond the expectations of the developers of the Internet must be the pervasive posture the technology has attained in the 21 st century. The Internet has spread its tentacles in virtually all spheres of human endeavour. Imperatively, developments in technology are fast expanding the frontiers of communication so that many more persons are reached through the various channels of communication than previously imagined. The $21 \mathrm{st}$ century has ushered us into the era of convenient and effective communication.

Interestingly, religious organizations do not only see the Internet as one of nature's greatest gifts to humanity but a tool primarily designed to facilitate the spread of the gospel. In whatever shape or form the religious organizations are, they are expected to propagate the doctrines of their faith to people across the world, with a view to converting them. For instance, the Great Commission in Christendom is a demand that Christians spread the gospel of Jesus Christ across the world. "Go ye, therefore, and teach all nations, baptizing them in the name of the Father, and the Son, and of the Holy Ghost" (Matthew 28:19; Mark 16:15). This great task had been more demanding than it is with the advent of the Internet and other technological innovations. Many religious organizations with a wide followership are beginning to find respite in reaching them through Internet-enabled communication channels.

Over time, religious organizations have been known to wield some reasonable degree of influence on their followers and society. With the needed resources at their disposal, they have consciously continued to sustain the communication flow between them and their (intending) adherents. Television, radio, newspapers and billboards, among others, have served as veritable channels for the propagation of religious messages. The Internet broadens the chances of reaching them. In fact, many churches have gone virtual. Just as religious organizations (especially Christianity) are fast establishing more physical branches across nations, so are their other branches extended on the various social media platforms. As churches continue to embrace the Internet and create virtual branches, it does appear that the innovation is fostering the ties between churches and their members. The Internet is creating an opportunity for a psychological link between churches and members, an opportunity that the physical church has not sufficiently created. Digital communication is giving us the opportunity to form more relationships and deepening existing ones (Smith, 2015). This chapter takes a critical look at how the Internet is shaping and redefining evangelism in the era of new media.

\section{The Thrust of the Paper}

The Internet is providing faster, affordable and a more convenient means of communication. Its impact on religious organizations in reaching their members is observably remarkable. However, not many Christian organizations have embraced the lofty disposition of the Internet. This is probably because of the financial involvement as the cost of sustaining evangelism online is prohibitive. This can explain why smaller churches are yet to see online evangelism as an option.

Again, many Christian organizations, either out of sheer religious fanaticism, apprehension or misinformation have written off the Internet as some "unrighteous" thing that is apparently not fit as a channel for religious messages hence they have literally thrown away the baby with the bath water. Their position is predicated on the many ignoble, vicious and immoral posts on the Internet via the social media platforms. Yet it can be contended that like any other medium, what one does with the Internet technology is purely one's choice. The medium itself is not the problem. 
Meanwhile, the number of new media users in a church will determine how far-reaching and engaging the messages via the Internet will be on its members. It is argued that since a great many new media users are youths, their gratifications could be derived from contents other than religious messages. This in itself is one of the core concerns of this paper; hence the need to determine the place of evangelism in the age of the new media.

\section{Objectives of the Study}

This entry examines evangelism in the era of new media by evangelical churches in Port Harcourt metropolis. In specific terms, it seeks to achieve the following:

1. Investigate the purposes for which the evangelical churches in Port Harcourt metropolis use the new media.

2. Determine the workability of online evangelism by evangelical churches in Port Harcourt metropolis.

3. Investigate the effectiveness or otherwise of the new media in fostering bonds among members of evangelical churches in Port Harcourt metropolis.

4. Identify the limitations or challenges of the use of new media as channels of communication by churches in Port Harcourt metropolis.

\section{Operational Definition of Terms}

Some of the terms used consistently in this work are operationalized as follows:

Church members: members of evangelical or Pentecostal churches in Port Harcourt metropolis

Evangelism: the act of propagating the gospel of Jesus Christ by churches in Port Harcourt metropolis, with the intention of converting their audience to their faith. Christianity is what is intended in this work with regard to evangelism, that is, soul winning to the Christian faith. No other religious group than Christianity calls its soul hunt evangelism.

Evangelical church: Church with emphasis on evangelism as its primary mission; many Pentecostal churches are evangelical.

New media: the Internet and other social media networks used by churches in Port Harcourt metropolis to reach out to their old, new and prospective members

Prospective members: people who are likely to be members through conversion following evangelism via the new media or through personal decision to be members

Religious organizations: places of worship and for practicing religious faiths, such as churches which are in focus in this work.

Social media: forms of new media comprising Facebook, Twitter, WhatsApp, LinkedIn and YouTube among others, used by evangelical churches in Port Harcourt metropolis to reach their audiences
The Great Commission: Christ's command that Christians should spread the gospel of Jesus Christ across the world, teaching and baptizing converts in the name of the Father, the Son and the Holy Spirit, as can be found in Matthew 28:19; and Mark 16:15.

\section{THEORETICAL FOUNDATION}

Every research draws inspiration from time-tested scholarly positions on the subject matter (Dii, 2018). Theories facilitate the understanding of issues in the affected field (Ohaja, 2003). Of the theories that provide a good foundation for this paper is the over-flogged Technological Determinism.

Propounded by McLuhan (1962) and cited in Edogor, Jonah and Ojo (2014), the technological determinism theory contends that "changes in communication technology inevitably produce profound changes in both culture and social order" (p.57). McLuhan, maintained that the new technology age is one that has never been experienced. The theory states that technology of communication shapes the way individuals think, feel and act and how societies organize themselves and operate (www.wongkeenling.com, cited in Asadu, 2014). The emergence of the new media into our communication ecology is fast revolutionizing the way people interact in society. It means that the new media (social media platforms) exercise some power on their users' patterns of exchanging information, opinions and messages. Owing to the interactive nature of the media, they offer their users distinct favour of communication unlike what is obtainable from other media genres (Edogor et al., 2014).

Featherstone and Burrows (1995), cited in Laskewicz (2008), observe the growing impact of the new media on our everyday lives and submit thus:

Technology is beginning to mediate our social relationships or self-identities and our wider sense of social life to an extent we are only beginning to grasp. The portable telephone, the portable fax, the notepad computer and various other forms of electronic/human augmentation have become "essential" for social life in the densely networked centres of the global cities and increasingly beyond (p.58).

The implication of this theory is that new media technologies are fast setting the line for social interaction. Conversely, arguments are rife that this theory increases the debate on information society. The emphasis placed on information overtly reveals that the world is moving into an information age. As a result of this, people have become news-conscious, data-minded and entertainment-crazy; a distillation of that will certainly reveal that news, data and entertainment are virtually products of the media (Okon, 2007). The emergence of the new media contributes to information overload. Again, Okon (2007) observes that:

This flood of information has been described by contemporary scholars as "Infoglut" - an information overload on the average individual. At this rate, individuals in the society may progressively become 
informative, informatory and hyper-informed. Teleconferencing and telecommuting are just windows into the information society phenomena (p.274).

Accordingly, the social media sites, a form of the new media, are shaping communication and social interactions even in religious circles.

\section{SOCIAL MEDIA USE: AN EMERGING TREND IN EVANGELISM}

In a bid to extend their membership beyond the limits of their geographical location, religious organizations are fast embracing technological alternatives to actualizing this. Eventually, they seem to have found in the social networking sites a veritable and convenient means of actualizing this cause. Evangelical online churches, which harness public preaching to spread gospel, have quickly adapted to online social media as their most effective form of mass communication (Lawrence, n.d). Through the various social media platforms like Facebook page or chatrooms, churches are bringing in members from around the world together in a single democratic space on the web (Lawrence n.d). Many Christian religious evangelists have adopted the mass media to produce and broadcast spectacular church services to a mass audience (Meyer, 2006).

Before now, the talk of religion online was new and sexy (Campbell, 2007). Now, the advancement in technology has helped Christian organizations to reach out to many more persons than previously imagined within the past decade. The religious application and implication of new technologies have attracted a lot of scholarship (Zateski, 1997; Bunt, 2000; Helland, 2000; Hodden \& Cowan, 2001, cited in Ihejirika, 2008). This was soon followed by the first academic studies on religion online, such as O'Leary's (1996) work on the ritual use of cyberspace as sacred space by Christians and pagans. In the mid1990s, researches started to invest time and interest in the role religion was playing in a variety of online environments (Campbell, 2007). Baym (2005) cited in Campbell (2007) notes that "now, a decade later, a substantial collection of studies and investigations is coming together, as the meeting of religion and the Internet is increasingly recognized as an important area within Internet studies" (p.1043). It is noteworthy that the increasing use of the Internet in the propagation of religious messages in Africa has warranted further research in this area of mass communication. Ihejirika (2008) confirms that "in Africa, the growing scholarship in the field of media, religion and culture has also started to investigate the growth of the new media...on the continent" (p.80). At a recent conference on New Media and Religious Transformation in Africa held in Abuja, Nigeria, a good number of papers focused explicitly on the new information and communication technologies and their appropriation by various religious groups, including the African Traditional Religion (Asamoah-Gyadu, 2003, cited in Ihejirika, 2008).
The use of the Internet by Christian organizations in Nigeria, as hinted earlier in targeted towards converting more persons to Christianity. Ihejirika (2008) argues that "it is a reflection of their globalizing aspirations, as well as a calculated attempt to transform and Christianize popular culture so that it is safe for consumption by born-again Christians" (p.81). A number of Christian organizations have very impressive, informative and regularly updated and functioning websites (Kuponu, 2015). Kuponu maintains that the websites of these churches have thus become markets of some sort, as well as an extension of the church building where materials like audio messages, videos, books and others emanating from them are sold to the public.

Prominent among churches in Nigeria with a seeming robust Internet presence are the Nigerian Pentecostals, which were quick in appropriating the new information technology, especially Internet and satellite broadcasting (Ihejirika, 2005). The most notable figures among them are: Tunde Bakare of the Latter Rain Assembly, Chris Oyakilome of Christ Embassy, Matthew Ashimolowo of Kingsway International Christian Centre, Enoch Adeboye of Redeemed Christian Church of God, Mike Okoronkwo of the Redeemed Evangelical Mission, David Oyedepo of the Living Faith Church and Bimbo Odukoya of the Fountain of Life Church (Ihejirika, 2008). It is instructive to note that smaller Christian organizations are also registering their presence on the social media sites.

A number of these Christian organizations have web radio and television, where members tune to get religious messages. For instance, the Living Faith Church, Redeemed Christian Church of God, Deeper Life Bible Church and a host of other evangelical churches now have live streaming web radio and television. The inevitability of the use of the Internet by these big evangelical churches is borne out of their global reach.

With a large followership across many nations, the Internet has enabled them to bridge the impediments of time, space, and distance in their bid to reach out to their followers. Amanze and Wogu (2015) hint that "revolutions in technology have prompted the use of the Internet for evangelism - the Internet has become a household method of soul winning" (p.150).

Talking of benefits, research has proved that the benefits of using the Internet for evangelism are enormous. These benefits as listed by Edmiston (2007) cited in Amanze and Wogu (2015), include: (1) low costs, (2) lower risk, (3) wider geographical reach, (4) ability to utilize multiple media formats, (5) ability to reach entire language groups, (6) convenience and accessibility. (7) It is seeker-driven; (8) ability to target particular niches, (9) ability to explain complex concepts and (10) enhanced credibility. Similarly, since the Internet appears to be the main domain of young minds, its use to target these set of persons might just be apt. Corroborating this position, Santrac (2011) argues that "outreach via the Internet is the best way to reach the post- 
modern mind and secular mind" (p.63). Sahlin (1998), cited in Amanze and Wogu (2015), are quick to add that "the only way to reach the urban mind is via urban techniques..." (p.151).

\section{EVANGELISM IN THE ERA OF THE INTERNET}

Evangelism is an improved form of Pentecostalism. Anderson (2014) cited in Kuponu (2015) writes that Pentecostalism began just a century ago and the movements continue to expand into the 21 st century. Pentecostals believe in the possibility of the gifts of the Holy Spirit with a great emphasis on the fact that the "bible pattern" of baptism in the spirit was an experience subsequent to salvation and evidenced by the ability to speak in tongues, perform miracles and manifest the other gifts of the Holy Spirit as stated clearly in the Bible (Ojo, 2006 cited in Kuponu, 2015). Kuponu, is of the view that

the power of influence of 'evangelization' in Pentecostal outreaches has often been hinged on the demonstrative effect of miracles claimed by some of their leaders and founders and they continue to have wider impact because of the contextualization of their emphasis and appropriation of traditional elements (Kuponu, 2015).

Asamoah-Gyadu (2012) submits that:

Evangelism has become a means of participating in religious globalization, and for a continent that feels marginalized in the modern world events, its contemporary Christian representations feel obliged to make their presence felt on the world stage. A lot of that happens through placing religion in the media and building up new virtual communities beyond physical audiences (p.126).

It is common knowledge that the television is restricted by coverage. It is this limitation in coverage of television for evangelism that has given rise to Internet evangelism. It is therefore imperative to state that within the context of this study, televangelism is synonymous with Internet evangelism. Moreover, it is expedient to note that the Internet is the best way to share the gospel in a digital age. It is one of the only ways for global evangelism (Doss, 2002, cited in Amanze \& Wogu, 2015). Evangelism is therefore caught up in a paradoxical situation; it is dependent for its very existence upon the same technologies of mass communication that have been instrumental in structuring and maintaining a world that conservative evangelists see as fallen or inauthentic, and evangelical programmes are therefore forced to share a media space (the airwaves, cable networks, and now the space of the digital) with the major channels and representatives of secular culture (Denson, 2011).

Evangelism has ushered Christian organizations and their followers into evangelical sphere. The evangelical sphere, is not situated outside but very much within the modern world; it is articulated through large religious media networks (including print media, cable television channels and websites) (Denson, 2011).

Evangelism has attracted a number of researchers to study the emerging phenomenon in mass communication studies. Some of these studies, especially those carried out in Africa fall under Helland's religion online. There are categorizations, like those that seek to show the globalization dimension of religious groups (or the projection of religious image and messages through the new media). Others fall under the category of online religion, like those that show how Africans, especially those in the Diaspora, are constructing their identities through the new media (Asamoah-Gyadu, 2003; Haron, 2004; Myer, 2001; Van Dyik, 2001, 2004, cited in Ihejirika, 2008).

Campbell (2007) examined the influence of the Internet and the extent to which it is challenging religious authorities. The study examined the concept of authority and how religious engagement online exerts authority on Internet users. The study aimed at providing more insight on religious authority and power relationships within online environment through a qualitative analysis of three sets of interviews with Christians, Jews and Muslims about the Internet. The study showed the different layers of authority in terms of hierarchy, structure, ideology and text as well as how it is discussed and contextualized differently to each religious tradition in terms of these four layers of authority (Campbell, 2007). The study argued that researching the question of authority in studies of religion and the Internet requires researchers to approach the concept of authority as multi-layered. It notes that there is a need to distinguish the different expressions of authority at play within online content (Campbell, 2007). The study probed into how the Internet affects religious authority, the need to identify clearly what specific form of authority is at play and the possible danger of failing to capture the complexity of the relationship between the online and offline religious communities.

Another study by Cheong (2008) looked at blogging as an interesting site of online religious communication. The study analyzed the content of 200 blogs with mentions of copies related to Christianity, as well as interviews of a subset of these bloggers, suggesting that blogs provide an integrative experience for the faithful, not a "third place" but a welding of the personal and communal, the sacred and the profane. The study revealed that by chronicling how they experience faith in their everyday lives, the bloggers aim to communicate not only to their communities and to a wider public but also to themselves.

More so, Ihejirika (2005) in a paper investigated the use of New Information and Communication Technologies (NICTs) by the Catholic Church in Nigeria. The paper was first presented in Nenary at the Sixth International Conference on Media, Religion and Culture, at the Methodist University of Sao Paulo, Brazil, July 11-14, 2008. The paper examined the level of application of indirect religious application of NICT 
otherwise referred to in the paper as an-in-line religion, while advancing a new perspective in studying the application of new information and communication technologies in religious belief and praxis in Africa. The paper revealed that there were 101 preachers, healers, counsellors, exorcists and singers who identify with this burgeoning movement within Christianity, and who buy airtime on national, local and private radio and television stations to proclaim their fundamentalist messages (Ihejirika, 2005). The paper further indicated that the Catholic Church has accepted and embraced the new information and communication technologies. It noted that there are still worries among some traditional Catholics about the possibility of the Internet to dilute essential catholic doctrines and practices, even though it admitted that the current attitude of the Catholic Church with regard to the new information and communication technologies is positive (Ihejirika, 2008).

The study had purposefully chosen Mater Cyberworld, an Internet Café owned by the Mater Ecclesial Catholic Diocese, Ahiara Mbaise, in Imo State, Eastern Nigeria, for the study. The choice of the cybercafé was informed by the rural nature of the community in which it is located and the fact that it remained functional several years after its take-off. Although the Mater Cyberworld is a one-case study, it reflects the appreciation of the new information and communication technologies by the Catholic Church in Nigeria. The paper made the following conclusions: (i) that the Pentecostal churches unlike the Catholic Church, are still ready to invest huge sums of money in setting up these new media technologies; (ii) Pentecostal websites are richer and more elegantly built than Catholic websites which just present the essential; (iii) Pentecostal use of the new media is directly religious in intent - providing users with Christian messages (through e-mail and SMS), while the Catholic use has indirect religious intent and that (iv) the Pentecostals target audiences in the middle class and upward mobile young adults, while the catholic effort seems more directed at the rural youths and the marginal urban dwellers (Ihejirika, 2005).

Meanwhile, the rapid upsurge in the use of information technology in all facets of life including religion, informed the study by Amanze and Wogu (2015). The study investigated the use of the Internet for evangelism by the Seventh Day Adventist Church, Nigeria. It showed that the Seventh Day Adventist Church in Nigeria has not yet harnessed the potential of the Internet even amidst its ubiquity (Amanze \& Wogu, 2015). The study examined the use of the Internet as an outreach method, while explaining the various ways by which the church in Nigeria can use the Internet for evangelistic purposes (Amanze \& Wogu, 2015). The study advocated the need to include Internet evangelism as an evangelistic strategy and pro

vides information for the effective use of the Internet in evangelization in the Seventh Day Adventist Church in Nigeria. It concluded that the changing times in which we live as well as the attendant benefits of the Internet for soul winning makes its use imperative.

\section{A DISCOURSE ON THE FINDINGS}

The new media are used by new media-compliant churches for education, information, socialization and evangelism. The new-media savvy persons encountered on the subject of online evangelism confirmed that their churches use the new media, particularly social media platforms, for evangelism. For them, churches which are ignorant of the potency of online evangelism are missing out on what is supposed to help them broaden the frontiers of fulfilling The Great Commission. The social media are the most used new media for evangelism by the churches. Of the social media used by churches, Facebook, Twitter, blogs, Instagram and WhatsApp are the most used for evangelism; and they are effective for their purpose. In the view of online evangelists, despite such unethical practices as cyber bullying, rumour peddling, incivility, sexting, pornographic transmissions, fake advertisements, online time wastage and cyber fraud/scam, the Internet should not be avoided because these practices are man-made, not inherent in the Internet technology itself.

How is evangelism done online? According to the interviewees, it is done through posting evangelical messages on Facebook and WhatsApp and through chats with converts who are being followed up. Nowadays, they state, video and audio clips of live testimonies are posted on social media platforms. So are notices of crusades, personal evangelism, special programmes, campus evangelism, fellowships and services uploaded to relevant platforms as a constant reminder of evangelical activities. Testimonies that touch on the challenges of the target audience members encourage the listeners or viewers to build their faith more firmly in the same God who has visited others and necessitated their testimonies. The effectiveness of online evangelism is high, meaning that online evangelism is succeeding above a mere average level.

Online evangelism helps in sustaining old members by fostering bonds among them as well as converting and following up new ones. Because they find evangelism satisfactory, online evangelists conclude that the churches which practice it are up-to-date.

\section{Limitations/Challenges of Online Evangelism and Possible Solutions}

There is a heated debate over the issue of the gratifications of online users. Because a great many of the target audience members of evangelical messages are youths, many believe as was earlier hinted in this work, that new media users could be gratified by contents other than religious messages. For instance, besides evangelism, the new media are used for education, information, socialization and entertainment. Evangelism is even among the least frequent uses of the new media.

Other challenges or limitations are high cost of sustenance of the enterprise of evangelizing online in the form of constant data subscription; erratic power supply or battery running low 
in the case of the use of mobile devices; and errors attendant to quick responses during chatting as one may want to type letters different from what the keyboards on mobile devices could suggest. Added to these is the inaccessibility of online messages to computer-illiterate members and prospective members of churches.

Among the suggestions we offer here for overcoming the challenges are:

(1) that there should be a budget for data subscription to avoid impulse buying that can affect the budget meant for other activities;

(2) that some well-to-do members can commit themselves to serving God in the area of data provision; and

(3) that there should be basic literacy training for the illiterate members of churches.

\section{CONCLUSION AND RECOMMENDATIONS}

On the basis of the findings of this study, it can be concluded that evangelical churches often make use of the social media for their evangelical activities; the Internet is used for education, entertainment, information, socialization and evangelism; the social media platforms mostly used for evangelism by evangelical churches are Facebook, Twitter, WhatsApp and Instagram; the churches that use the social media platforms are perceived to be up-to-date; and that although the social media used in evangelism are perceived as attractive and satisfactory, the cost of maintaining only sites is prohibitive.

The paper, therefore, recommends, amongst other things, that:

1. Churches and ministries should realize that times are fast changing and that most people have changed their means of accessing information for which reason a majority of people now use the new media of communication. Efforts, therefore, should be made by hesitant churches to create their own websites or social media platforms and even virtual communities.

2. Churches that are still hesitating should see new media evangelical communication as a trendy form of communication that can be packaged and harnessed for their benefit and so should predispose their minds to tap more from the resources of the technology by using the same new media devices to access information on evangelism.

3. Adherents of religious faiths as well as members of the mass audience who want to glean information from religious communication can go to appropriate online sites and gratify themselves.

\section{REFERENCES}

[1] Asadu, C.A. (2014). An assessment of the influence of unsolicited GSM text messages on the students of the University of Port
Harcourt. Review of Communication and Media Studies, 1(1), 4958.

[2] Asamoah-Gyadu, J.K. (2005). Anointing through the screen: NeoPentecostalism and televised Christianity in Ghana,Studies in World Christianity 11(1), $12 . \quad$ http:/l dx.doi.org/10.3366/swc.2005.11.1.9

[3] Cheong, P.H., Halavais, A. \& Kwon, K. (2008). The chronicles of me: Understanding blogging as a religious practice. Journals of Media and Religion, 7, 107-131.

[4] Denson, S. (2011). Faith in technology: Televangelism and the medication of immediate experience. Phenomenology \& Practice, 5(2), 96-122.

[5] Dii, B. (2018). Application of social media in the marketing of made-in-Nigeria products. An MA thesis presented in the Department of Mass Communication, RSU.

[6] Edogor, I.O., Jonah, A.A. \& Ojo, L.I. (2014). Influence of social media on youths' usage of traditional mass media in Nigeria. New Media and Mass Communication, 31, 55-65.

[7] Helland, C. (2005). Online religion as lived religion: Methodological issues in the study of religious participation on the Internet. Online Heidelberg Journal of Religions on the Internet, 1(1), 1-15.

[8] Ihejirika, W. (2005). Media and fundamentalism in Nigeria. Media Development, 38-44.

[9] Ihejirika, W.C. (2008). In-line religion: Innovative pastoral applications of the new information and communication technologies (NICTS) by the Catholic Church in Nigeria. A paper presented in plenary at the Sixth International Conference on Media, Religion and Culture at the Methodist University of Sao Paulo Brazil, July 11- 14. 2

[10] Kuponu, S.I. (2015). Pentecostalism and media: A reflection on space contestation on the internet. International of Journal of Social Sciences and Humanities Reviews, 5(1), 74-78.

[11] Laskewicz, Z. (2008). The impact of television and the internet: Are we constructed by socially instituted technologies or is technological determinism itself a construction? Retrieved May 30, 2018 from www.nachtschimmen.en/zachar/ writer/0701_techtm.

[12] Lawrence, E. (n.d). Evangelical social media and the use of interactive platforms to foster a non-interactive community. Retrieved May 16, 2018 from www.live.ifechukwu.tv.

[13] Meyer, B. (2006). Religious sensations. Why media, aesthetics and power matter in the study of contemporary religion. Amsterdam: Vrije University Press.

[14] Okon, G.B. (2007). Basic dimension in mass communication. Port Harcourt: HDX Communication Ltd.

[15] Smith, P. (2015). Meaningful communities: The growth of virtual churches. Retrieved May 18, 2018 from www.diocesesofoxford.com. 